\title{
UJI AKTIVITAS ANTIBAKTERI ALGA COKLAT JENIS Padina sp. DARI PANTAI SORIDO BIAK TERHADAP BAKTERI Staphylococcus aureus DAN Shigella dysenteriae
}

\author{
Putri Nuzul $^{1)}$, Daniel Lantang ${ }^{2)}$, Septriyanto Dirgantara ${ }^{3)}$ \\ ${ }^{1)}$ Program Studi Farmasi, FMIPA Universitas Cenderawasih, Jayapura-Papua \\ ${ }^{2)}$ Jurusan Biologi Fakultas MIPA Universitas Cenderawasih, Jayapura \\ Kampus UNCEN Waena. J1 Perumnas III Waena Jayapura 99351 Papua \\ Email*: putrinuzulkabaret@gmail.com
}

\begin{abstract}
Infections that drug resistant especially with bacterial involvement are still major challenges. Therefore, it is essential to discover new antibiotic compounds from marine resources such as algae. There are numerous of compounds derived from algae with a broad range of biological activities, incluiding antibacterial agent. The objective of this research are to know antibacterial activity of Padina sp. from different solvents on Staphylococcus aureus and Shigella dysenteriae and to know the extract of Padina sp. which most effectively inhibits development of Staphylococcus aureus and Shigella dysenteriae. Stages of this works includes: manufacturing crude drug, extraction by stratified maceration method using solvent, eq diethyl ether, ethyl acetate, and ethanol 96\%, screening phytochemical and exameration of antibacterial activity using disc diffusion method. The result was demonstrated that antibacterial activity of extract brown algae Padina sp. have ability to inhibit the growth of Staphylococcus aureus and Shigella dysenteriae. Several solvent in extraction of Padina sp. provides different antibacterial activity in which antibacterial activity with the better inhibitory zone against Staphylococcus aureus is with ethyl acetate solvent and antibacterial activity with the best inhibitory zone against Shigella dysenteriae with ethanol $96 \%$ solvent. The most effective brown algae extract (Padina sp.) on Staphylococcus aureus bacterial is ethyl acetate solvent with 100 ppm concentration of 12,66 mm and Shigella dysenteriae bacterial is ethyl acetate solvent with $250 \mathrm{ppm}$ concentration that is $10,69 \mathrm{~mm}$.
\end{abstract}

Keywords: Antibactery agents, Padina sp., Staphylococcus aureus, Shigella dysenteriae

\begin{abstract}
ABSTRAK
Infeksi yang resistan terhadap obat terutama dengan keterlibatan bakteri masih merupakan tantangan besar. Oleh karena itu, sangat penting untuk menemukan senyawa antibiotik baru dari sumber laut termasuk alga. Alga merupakan sumber laut yang kaya akan ragam metabolit sekunder. Ada banyak senyawa yang berasal dari alga yang didukung dengan berbagai aktivitas biologis, termasuk antibakteri. Tujuan dari penelitian ini adalah untuk menguji aktivitas antibakteri Padina sp. dari pelarut yang berbeda terhadap bakteri Staphylococcus aureus dan Shigella dysenteriae dan untuk mengetahui ekstrak Padina sp. yang paling efektif menghambat pertumbuhan bakteri Staphylococcus aureus dan Shigella dysenteriae. Tahapan kerja meliputi: pembuatan simplisia, pembuatan ekstrak dengan metode maserasi bertingkat menggunakan pelarut dietil eter, etil asetat, dan etanol $96 \%$, identifikasi senyawa fitokimia, dan uji aktivitas antibakteri dengan metode difusi cakram. Hasil penelitian menunjukkan bahwa ekstrak alga coklat jenis Padina sp. mampu menghambat pertumbuan bakteri Staphylococcus aureus dan Shigella dysenteriae. Perbedaan pelarut pada ekstraksi Padina sp. memberikan aktivitas antibakteri yang berbeda dimana aktivitas antibakteri dengan zona hambat terbaik terhadap bakteri Staphylococcus aureus yaitu dengan pelarut etil asetat dan aktivitas antibakteri dengan zona hambat terbaik terhadap bakteri Shigella dysenteriae yaitu dengan pelarut etanol 96\%. Ekstrak alga coklat (Padina sp.) yang paling efektif untuk bakteri Staphylococcus aureus adalah pelarut etil asetat dengan konsentrasi $100 \mathrm{ppm}$ yaitu $12,66 \mathrm{~mm}$ dan bakteri Shigella dysenteriae adalah pelarut etil asetat dengan konsentrasi $250 \mathrm{ppm}$ yaitu $10,69 \mathrm{~mm}$.
\end{abstract}

Kata Kunci: Antibakteri, Padina sp., Staphylococcus aureus, Shigella dysenteriae 


\section{PENDAHULUAN}

Dua pertiga dari luas negara Indonesia terdiri dari laut dan dilalui garis khatulistiwa serta kaya akan sumberdaya laut. Di samping fauna laut yang beraneka ragam dijumpai juga flora laut seperti alga yang dapat dimanfaatkan untuk makanan, obat-obatan, dan bahan baku farmasi lainnya. Indonesia mempunyai suatu peluang yang sangat besar dalam pemanfaatan hasil-hasil dari sektor kelautan, terutama dalam pemanfaatan alga yang berhubungan dengan bidang kesehatan dan obat-obatan (Zatnika, 2007).

Alga merupakan sumber daya yang kaya akan berbagai metabolit sekunder. Ada banyak senyawa yang berasal dari alga yang didukung dengan berbagai aktivitas biologis, seperti antibakteri (Dulger dan Dulger, 2014).

Berdasarkan hasil penelitian Tuney dkk (2006), ekstrak Padina pavonica dengan pengekstrak etanol menunjukkan aktivitas antijamur yang lemah terhadap Candida, Enterococcus faecalis dan antibakteri terhadap Pseudomonas aeruginosa dan Escherichia coli. Menurut Kandhasamy dan Arunachalam (2008), ekstrak Padina tetrastromica dengan pengekstrak metanol dapat menghambat pertumbuhan Klebsiella pneumoniae, E. aerogenes, $M$. luteus, E. faecalis, $S$. aureus, $P$. aeruginosa tetapi tidak dapat menghambat pertumbuhan E. coli. Menurut Ponnanikajamideen dkk (2014), dalam ekstrak pelarut yang berbeda dari Padina tetrastromatica telah menunjukkan aktivitas antibakteri terhadap Streptococcus sp., dan Bacillus subtilis.

Penyakit menular adalah salah satu penyebab utama kematian yang tinggi di kehidupan masyarakat global. Infeksi yang resistan terhadap obat terutama dengan keterlibatan bakteri masih merupakan tantangan besar. Oleh karena itu, sangat penting untuk menemukan senyawa antibiotik baru dari sumber laut. Sumber alam laut seperti rumput laut dan ganggang laut dapat menjadi alternatif yang sangat baik untuk memperbaiki situasi dengan penyaringan, pengembangan dan pembuatan senyawa antibakteri dan antijamur dari zat-zat bioaktif baru. (Taherpour dkk, 2016).

Infeksi masih merupakan penyakit utama dan penyebab kematian nomor satu. Oleh karena itu, penggunaan antibakteri atau antiinfeksi masih paling dominan dalam pelayanan kesehatan. Penyakit infeksi merupakan salah satu penyakit yang terus berkembang di Indonesia. Infeksi merupakan penyakit yang dapat ditularkan dari satu orang ke orang lain atau dari hewan ke manusia (Priyanto, 2008).

Pada umumnya Padina sp. tidak banyak dimanfaatkan oleh masyarakat. Padina sp. banyak ditemukan di pinggir pantai dan sebagian hanyut terbawa ombak. Dari uraian diatas, maka peneliti tertarik untuk melakukan penelitian tentang "uji aktivitas antibakteri alga coklat (padina sp.) terhadap bakteri Staphylococcus Aureus dan Shigella dysenteriae" sehingga dapat dijadikan sebagai penelitian awal dalam hal kaitannya penemuan dan pengembangan antibiotika baru dari bahan alam.

\section{METODE PENELITIAN}

Alat-alat yang digunakan: Alat-alat gelas, blender, cawan petri, mikropipet, autoklaf, jangka sorong, timbangan analitik, 
pembakar bunsen, magnetik stirer, pinset, kawat ose, inkubator, rotary evapoator, hot plate, vortex, lemari pendingin, dan laminar air flow (LAF).

Bahan-bahan yang digunakab: Sampel alga coklat (Padina sp.), larutan etanol 96\%, aquades, air suling steril, kertas saring, cipro (pembanding positif), dan media NA.

\section{Lokasi Dan Waktu Penelitian}

Penelitian dilakukan di Laboratorium Mikrobiologi Jurusan Biologi Fakultas Matematika dan Ilmu Pengetahuan Alam Universitas Cenderawasih. Waktu penelitian dilakukan 4 bulan, dimulai pada bulan Januari-April 2017.

\section{Pengumpulan Sampel}

Sampel Padina sp. diambil dan dikumpulkan dari pantai Sorido Biak. Pengambilan sampel dilakukan dengan menyisir pantai dan adapun cara pengambilan sampel diambil dengan menggunakan tangan. Setelah diambil, dicuci dengan air laut untuk menghilangkan pasir-pasir dan kotoran. Lalu dimasukkan kedalam kantong plastik selama pengangkutan.

\section{Pembuatan Simplisia}

Sampel Padina sp. yang didapatkan selanjutnya dibersihkan dengan menggunakan air tawar yang mengalir untuk membersihkan kotoran-kotoran dan garam-garam yang masih menempel. Kemudian sampel direndam selama tiga hari dengan tujan untuk menghilangkan garamnya. Selanjutnya sampel ditiriskan, ditimbang dan dikeringkan dengan menggunakan sinar matahari hingga kering. Sampel yang sudah dikeringkan, kemudian dihancurkan dengan menggunakan blender menjadi serbuk halus. Selanjutnya sampel diayak menggunakan ayakan dengan mesh 60 untuk mendapatkan butiran yang seragam.

\section{Pembuatan Ekstrak}

Proses pembuatan ekstrak dilakukan dengan menggunakan metode maserasi bertingkat dengan menggunakan pelarut dietil eter, etil asetat dan etanol 96\%. Serbuk Padina sp. sebanyak 500 gram direndam dengan pelarut dietil eter $1.500 \mathrm{ml}$ (perbandingan 1:3) direndam selama 3 hari dengan sekali sehari diaduk, kemudian disaring sehingga diperoleh filtrat dietil eter dan residu dietil eter. Residu dietil eter dimaserasi kembali dalam pelarut etil asetat dengan perbandingan 1:3 selama 3 hari dengan sekali sehari diaduk. Setelah itu, disaring lagi untuk mendapatkan filtrat etil asetat dan Residu etil asetat. Hal yang sama dilakukan untuk memperolah Filtrat etanol 96\% dan Residu etanol 96\%. Selanjutnya, filtrat dietil eter, etil asetat, dan etanol $96 \%$ diuapkan menggunakan rotavapor dan di uapkan dengan bantuan waterbath sehingga didapatkan ekstrak pekat. Rendemen yang diperoleh kemudian ditimbang dan dicatat.

\section{Uji Aktivitas Antibakteri}

Konsentrasi ekstrak yang digunakan dalam pengujian adalam 1000 ppm, 750 ppm, 500 ppm, 250 ppm dan 100 ppm. Dibuat konsentrasi ekstrak Padina sp. setiap pelarut dengan konsentrasi dengan larutan stok 1000 ppm sebanyak 10 $\mathrm{ml}$ dan dilanjutkan pengenceran untuk mendapatkan konsentrasi 750 ppm, 500 ppm, 250 ppm dan 100 ppm sesuai dengan tentang pembuatan konsentrasi ekstrak.

Pengujian aktivitas antibakteri dari ekstrak Padina sp. Terhadap Staphylococcus aureus dan Shigella dysenteriae yang 
dilakukan dengan menggunakan metode difusi cakram. Pada metode ini dilihat daerah bening yang dihasilkan disekitar cakram.Media agar yang sudah dituangkan dalam cawan petri steril, kemudian biarkan memadat pada suhu kamar. Setelah memadat, suspensi bakteri yang telah dibuat, diratakan pada permukaan media agar dengan menggunakan batang L secara merata. Kertas cakram steril direndam kedalam semua larutan uji yang akan digunakan yaitu larutan ekstrak uji, kontrol negatif dan kontrol positif. Setelah itu, kertas cakram didiamkan beberapa saat agar menyerap larutan uji \pm 1 menit, kemudian diletakkan pada permukaan agar dengan menggunakan pinset steril. Kontrol negatif digunakan akuades steril dan kontrol positif digunakan ciprofloksasin $5 \mu \mathrm{g}$. Kemudian diinkubasikan pada suhu $37^{\circ} \mathrm{C}$ selama 24 jam. Selama 24 jam diinkubasi, diamati zona bening dan diukur dengan menggunakan menggunakan jangka sorong. Pengujian dilakukan dengan 3 kali pengulangan.

\section{Analisis Data}

Data hasil pengujian aktivitas Padina sp. terhadap diameter zona hambat pertumbuhan bakteri dianalisa dengan metode Rancangan Acak Lengkap (RAL) dengan 7 perlakuan dan $3 \mathrm{x}$ pengulangan. 7 perlakuan yang dimaksud adalah dengan menggunakan konsentrasi 1000 ppm, 750 ppm, 500 ppm, 250 ppm 100 ppm, kontrol positif yaitu ciprofloksasin dan kontrol negatif yaitu aquades steril. Jika Analisis varians (Anova) menunjukkan konsentrasi perlakuan yang diteliti berbeda nyata dengan kontrol, maka dilakukan uji lanjut dengan menggunakan uji BNJ.

\section{HASIL DAN PEMBAHASAN}

\section{Pembuatan Ekstrak}

Metode maserasi bertingkat dapat menghasilkan ekstrak cair yang berkualitas dibandingkan metode maserasi tidak bertingkat karena metode maserasi bertingkat semua senyawa kimia dalam simplisia dapat terdistribusi berdasarkan kepolaran pelarut yang digunakan. Pelarut n-heksan akan menarik senyawa non-polar begitupun dengan etil asetat menarik senyawa semi polar sehingga dengan mudah metanol menarik senyawa polar tanpa ada gangguan yang ikut terekstrak dari senyawa golongan lain (Maharani dkk, 2017).

Prinsip maserasi adalah merendam serbuk dalam pelarut yang sesuai selama beberapa hari. Pelarut akan masuk kedalam sel tanaman melewati dinding sel. Zat atau isi sel akan larut karena adanya perbedaan konsentrasi antara larutan didalam sel dengan diluar sel. Larutan dengan konsentrasinya tinggi akan terdesak keluar dan diganti oleh pelarut dengan konsentrasi rendah (proses difusi). Peristiwa ini akan berulang sampai terjadi keseimbangan antara larutan didalam sel dan larutan diluar sel. Dalam perendaman juga dilakukan pengadukan sehari sekali. Hal ini dilakukan karena menurut Wardani dkk (2011), dengan pengadukan yang dilakukan secara berkala maka akan didapatkan kesetimbangan konsentrasi bahan aktif yang cepat dan merata didalam cairan.

Dari hasil pembuatan ekstrak dengan maserasi bertingkat ini mendapatkan hasil rendemen untuk pelarut dietil eter sebesar $0,16 \%$, untuk pelarut etil asetat sebesar $0,26 \%$ dan untuk pelarut etanol $96 \%$ sebesar 1,30\%. Dari hasil rendemen dapat dilihat bahwa hasil rendemen dengan pelarut etanol 96\% merupakan rendeman terbanyak. Hal ini sesuai dengan hasil penelitian 
Podungge (2012) yang menyatakan proses ekstraksi Padina australis dengan pelarut berbeda yang dilakukan menghasilkan rendemen terbanyak pada ekstrak dengan pelarut polar. Hasil ekstrak kental ini juga sesuai dengan penelitian Maharani dkk (2017) yang melakukan maserasi pada Padina australis dengan tiga pelarut yang berbeda yaitu methanol, etil asetat dan n-heksan yang mendapatkan hasil terbanyak pada pelarut polar yaitu methanol dengan \% rendemen yaitu pelarut n-heksan $0,45 \%$, etil asetat $0,8 \%$ dan methanol 4,55\%. Hasil pembuatan ektrak alga coklat jenis Padina sp., tetera pada tabel 1 .

\section{Tabel 1. Hasil Pembuatan Ekstrak}

\begin{tabular}{lccc}
\hline Pelarut & $\begin{array}{c}\text { Berat simplisia } \\
\text { awal (gram) }\end{array}$ & $\begin{array}{c}\text { Berat Ektrak } \\
\text { (gram) }\end{array}$ & Rendemen (\%) \\
\hline Dietil Eter & 500 & 0,784 & $0,16 \%$ \\
Etil Asetat & 500 & 1,295 & $0,26 \%$ \\
Etanol 96\% & 500 & 6,502 & $1,30 \%$ \\
\hline
\end{tabular}

\section{Penapisan Fitokimia}

Hasil penapisan fitokimia Padina sp. tertera pada tabel 2

Tabel 2. Hasil Penapisan Fitokimia Simplisia dan Ekstrak

\begin{tabular}{lcccc}
\hline & \multicolumn{4}{c}{ Hasil } \\
\cline { 2 - 5 } Pengujian & Simplisia & $\begin{array}{c}\text { Ekstrak } \\
\text { Dietil Eter }\end{array}$ & $\begin{array}{c}\text { Ekstrak } \\
\text { Etil Asetat }\end{array}$ & $\begin{array}{c}\text { Ekstrak } \\
\text { Etanol }\end{array}$ \\
\hline Alkaloid & - & - & - & - \\
Flavonoid & - & + & + & + \\
Kuinon & - & - & - & - \\
Saponin & + & - & - & - \\
Steroid & - & - & - & - \\
Tanin & - & - & - & - \\
\hline
\end{tabular}

Keterangan: + Terdeteksi

- Tidak terdeteksi

Hasil penapisan fitokimia dari simplisia alga coklat jenis Padina sp. menunjukkan hasil positif saponin dan tidak terdeteksi adanya senyawa alkaloid, flavonoid, kuinon, steroid dan tanin. Adanya senyawa saponin ditandai dengan terbentuknya busa yang bertahan tidak kurang dari 10 menit. Busa yang terbentuk bila ditetesi dengan asam klorida tidak akan hilang, hal ini karena saponin adalah senyawa aktif dengan permukaan kuat yang menimbulkan busa bila dikocok dalam air (Robinson, 1991). Saponin merupakan glikosida triterpen yang memiliki sifat cenderung polar karena ikatan glikosidanya (Harbone, 1987). Rumput laut coklat juga diketahui mengandung senyawa flavonoid. Flavonoid merupakan golongan terbesar senyawa fenolik yang memiliki gugus kromofor. Gugus kromofor tersebut 
menyebabkan kemampuan untuk menyerap gelombang sinar UV (Maharani dkk,2017).

Adanya senyawa flavonoid ditandai dengan terbentuknya warna jingga, kuning atau merah yang tertarik pada lapisan amil alkohol, hal ini terjadi karena terjadi reduksi antara $\mathrm{Mg}$ dan $\mathrm{HCl}$ pekat menghasilkan senyawa kompleks yang berwarna merah atau jingga (Robinson, 1995). Flavonoid umumnya lebih mudah larut dalam air atau pelarut polar dikarenakan memiliki ikatan dengan gugus gula (Markham, 1988).

Penelitian Maharani dkk (2017) menyatakan bahwa ekstrak n-heksana Padina australis positif mengandung flavonoid, fenol hidrokuinon, triterpenoid, saponin dan tanin.

Menurut

Podungge

(2012) senyawa

bioaktif yang

Konsentrasi
$(\mathrm{ppm})$

dimiliki oleh ekstrak $P$. australis yaitu flavonoid, steroid dan saponin diketahui memiliki potensi sebagai antibakteri. Menurut saloso dkk (2011) ekstrak metanol positif mengandung steroid, terpenoid, saponin dan polifenol.

\section{Uji Aktivitas Antibakteri}

Uji aktivitas antibakteri ekstrak alga coklat jenis Padina sp. dengan konsentrasi 100 ppm, 250 ppm, 500 ppm, 750 ppm dan 1000 ppm terhadap bakteri Staphylococcus aureus (gram positif) dan Shigella dysenteriae (gram negatif) menggunakan metode difusi cakram.

\begin{tabular}{ccccc} 
Tabel 3. & $\mathrm{K}(-)$ Akuades & 0,00 & 0,00 & 0,00 \\
Hambat & 100 & 8,95 & 8,68 & 8,67 \\
bakteri & 250 & 9,04 & 10,69 & 8,87 \\
& 500 & 9,05 & 11,52 & 8,91 \\
& 750 & 9,81 & 12,57 & 12,27 \\
& 1000 & 10,44 & 12,68 & 12,78 \\
& $\mathrm{~K}(+)$ Cipro $5 \mu \mathrm{g}$ & 36,09 & 36,09 & 36,09 \\
\hline
\end{tabular}

Hasil Zona

Diameter Zona Hambat (mm)

Shigella dysenteriae

Staphylococcus aureus.

Tabel 4. Hasil Zona Hambat Terhadap bakteri Shigella dysenteriae.

\begin{tabular}{cc}
\hline $\begin{array}{c}\text { Konsentrasi } \\
(\mathrm{ppm})\end{array}$ & Diameter Zona Hambat $(\mathrm{mm})$ \\
& Staphylococcus aureus \\
\hline
\end{tabular}




\begin{tabular}{cccc}
\cline { 2 - 4 } & Dietil Eter & Etil Asetat & Etanol \\
\hline $\mathrm{K}(-)$ Akuades & 0,00 & 0,00 & 0,00 \\
100 & 9,49 & 12,66 & 7,59 \\
250 & 9,63 & 13,64 & 8,17 \\
500 & 9,82 & 13,94 & 9,32 \\
750 & 9,67 & 15,12 & 10,09 \\
1000 & 9,94 & 17,06 & 10,57 \\
$\mathrm{~K}(+)$ Cipro 5 $\mu \mathrm{g}$ & 22,98 & 22,98 & 22,98 \\
\hline
\end{tabular}

Menurut Davis dan Stout (1971), yaitu zona hambat bakteri kurang dari $5 \mathrm{~mm}$ dikategorikan lemah, untuk zona hambat 5 $\mathrm{mm}-10 \mathrm{~mm}$ dikategorikan sedang, zona hambat $10 \mathrm{~mm}-20 \mathrm{~mm}$ dikategorikan kuat dan untuk lebih dari $20 \mathrm{~mm}$ dikategorikan sangat kuat, dari kriteria daya hambat tersebut maka pada tabel 3 daya hambat alga coklat jenis Padina sp. terhadap bakteri Staphylococcus aureus dengan pelarut dietil eter termasuk dalam kategori lemah karena tidak lebih dari $10 \mathrm{~mm}$. pada pelarut etil asetat zona hambat termasuk dalam kategori kuat berkisar dari $12 \mathrm{~mm}-17 \mathrm{~mm}$ dan pada pelarut etanol 96\% masuk kategori lemah untuk ekstrak dengan konsentrasi 100 ppm $(7,59$ $\mathrm{mm}), 250$ ppm (8,17 mm), 500 ppm $(9,32)$ dan kategori kuat untuk konsentrasi 750 ppm $(10,09 \mathrm{~mm})$ dan $1000 \mathrm{ppm}(10,57 \mathrm{~mm})$.

Pada tabel 4 zona hambat terhadap bakteri Shigella dysenteriae dengan pelarut dietil eter termassuk kategori lemah pada konsentrasi $100 \mathrm{ppm}(8,95 \mathrm{~mm}), 250 \mathrm{ppm}$ $(9,04 \mathrm{~mm}), 500 \mathrm{ppm}(9,05 \mathrm{~mm}), 750 \mathrm{ppm}$ $(9,81 \mathrm{~mm})$ dan kategori kuat untuk 1000 ppm $(10,44 \mathrm{~mm})$. Pada pelarut etil asetat kategori lemah pada konsentrasi $100 \mathrm{ppm}(8,68 \mathrm{~mm})$ dan kategori kuat untuk 250 ppm $(10,69 \mathrm{~mm})$, $500 \mathrm{ppm}(11,52 \mathrm{~mm}), 750 \mathrm{ppm}(12,57 \mathrm{~mm})$ dan 1000 ppm (12,68 mm). Selanjutnya pada pelarut etanol kategori lemah pada konsentrasi $100 \mathrm{ppm}(8,67 \mathrm{~mm}), 250 \mathrm{ppm}$ $(8,87 \mathrm{~mm}), 500 \mathrm{ppm}(8,91 \mathrm{~mm})$ dan kategori kuat untuk $750 \mathrm{ppm}(12,27 \mathrm{~mm})$ serta 1000 ppm $(12,78 \mathrm{~mm})$.

Hasil penelitian ini didukung dengan penelitian sebelumnya. Menurut Kayalvizhi dkk (2012) yang menguji ekstrak metanol dan kloroform dari Padina boergessenii terhadap
C. albicans, A. flavus, E. coli, S. Aureus menunjukkan $C$. albicans tahan terhadap ekstrak kloroform sedangkan A. flavus, $E$. coli, dan $S$. Aureus sensitif terhadap ekstrak yang diperiksa. Pada penelitian Dulger dan Dulger (2014) menguji antibakteri ekstrak etanol dan air Padina pavonica positif terhadap S. Aureus. Penelitian Ismail amel dkk (2016) ekstrak methanol dari Padina pavonica sebagai antibakteri memberikan hasil positif terhadap $S$. aureus, $S$. typhimurium, dan Micrococcus sp. Penelitian El-fatimy dan Said (2011) ekstrak methanol dan kloroform-metanol (2:1) Padina sp. memberikan pengaruh yang signifikan ketika diuji melawan bakteri $E$. coli dan $S$. aureus.

Pada beberapa penelitian Padina sp. terhadap Shigella sp. didapatkan hasil tidak adanya aktivitas antibakteri. Menurut Kemer dkk (2015) ekstrak etanol Padina australis tidak menimbulkan adanya zona hambat pada bakteri Shigella dysenteriae. Hal serupa juga sesuai dengan penelitian Taherpour (2016) bahwa ekstrak metanol, etil asetat, kloroform dan heksana dengan metode sokletasi bertingkat tidak menimbulkan adanya zona hambat pada bakteri Shigella sp.

Berdasarkan hasil uji akivitas antibakteri ekstrak alga coklat jenis Padina sp. dengan tiga pelarut terhadap 2 bakteri dimana semakin besar konsentrasi ekstrak maka semakin besar pula diameter zona hambatnya.Hal ini sesuai dengan penelitian Demirel dkk (2009) bahwa dengan meningkatnya konsentrasi ekstrak heksana dari alga coklat, penghambatan pertumbuhan $S$. aureus atau aktivitas antimikroba juga meningkat. Oleh karena itu, peningkatan konsentrasi ekstrak 
menyebabkan potensi kegiatan antimikroba yang lebih tinggi. Hal inipun sesuai dengan pendapat zailanie Kartini (2016) melakukan uji aktivitas antibakteri ekstrak methanol dan aseton Padina australis terhadap Salmonella typhi bahwa semakin tinggi konsentrasi aktivitas antibakteri ekstrak Padina australis maka antibakteri akan semakin kuat.

Selain itu hasil dari pengujian juga menunjukkan bahwa diameter zona hambat pada bakteri gram positif lebih besar dari pada gram negatif. Hal ini menunjukkan bahwa senyawa antibakteri dari alga coklat jenis Padina sp. lebih sensitif pada bakteri gram positif daripada bakteri gram negatif. Hal ini sesuai dengan penelitian dari Taherpour dkk (2016) serta Kandhasamy dan Arunachalam (2008) bahwa ekstrak Padina sp. lebih efektif terhadap bakteri Gram positif dibandingkan dengan bakteri Gram negatif.

Berdasarkan hasil pengukuran ratarata zona hambat dari tiga ekstrak Padina sp. terhadap Staphylococcus aureus dan Shigella dysenteriae, maka dibuat hasil analisis ragam untuk mencari perbedaan nyata antara setiap perlakuan.

Berdasarkan hasil analisis ragam dapat dilihat bahwa nilai F.Hitung kedua bakteri yaitu Staphylococcus aureus dan Shigella dysenteriae lebih besar dari F.Tabel, sehingga terdapat perbedaan bermakna atau ada pengaruh perlakuan jenis bakteri terhadap diameter zona hambat bakteri Staphylococcus aureus dan Shigella dysenteriae. Hal ini menunjukkan bahwa adanya perbedaan bermakna antara perlakuan sehingga dilakukan uji lanjut BNJ (Beda Nyata Jujur) untuk mengetahui perbedaan perlakuan tiap konsentrasi ekstrak yang dibandingkan mempunyai aktivitas yang berbeda nyata secara statistik atau tidak dan untuk mengetahui ekstrak apa dan pada konsentrasi berapakah yang paling efektif dalam.menghambat pertumbuhan bakteri.

Dari hasil uji $\mathrm{BNJ}_{0,05}$ yang diamati didapatkan hasil bahwa kontrol negatif menunjukkan perbedaan yang nyata terhadap kontral positif. kontrol negatif yang digunakan adalah akuades steril yang menunjukkan tidak adanya daerah hambat. Hal ini membuktikan bahwa kontrol negatif yang digunakan tidak berpengaruh pada pengujian antibakteri. Kontrol positif menunjukkan perbedaan nyata pada uji BNJ, karena menghasilkan aktivitas antibakteri yang besar terhadap bakteri uji.

Dari hasil uji $\mathrm{BNJ}_{0,05}$ didapatkan efek antibakteri yang paling efektif dari tiga pelarut untuk bakteri Staphylococcus aureus adalah pada pelarut etil asetat dengan konsentrasi 100 ppm (Gambar 1) yaitu dengan zona hambat yang terbentuk 12,66 mm. hal ini karena untuk mendapatkan kandidat antibakteri yang baik diperlukan konsentrasi sekecil mungkin dengan hasil ataupun zona hambat yang besar dan dari ketiga pelarut memiliki konsentrasi terbaik pada 100 ppm namun pada ekstrak etil asetat dengan konsentrasi $100 \mathrm{ppm}$ terbentuk zona hambat sebesar 12,66 $\mathrm{mm}$ dan termasuk dalam zona hambat kuat.

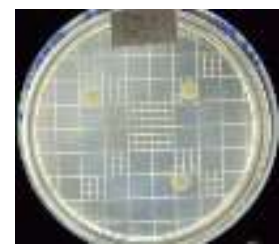

Gambar 1. Zona Hambat Ekstrak Etil Asetat 100 ppm Terhadap S. aureus

Dari hasil uji $\mathrm{BNJ}_{0,05}$ didapatkan efek antibakteri yang paling efektif dari tiga pelarut untuk bakteri Shigella dysenteriae adalah pelarut etil asetat dengan konsentrasi
250 ppm yaitu dengan zona hambat yang terbentuk 10,69 $\mathrm{mm}$. Hal ini karena dari ketiga pelarut untuk dietil eter konsentrasi efektif pada 1000 ppm dengan zona hambat 
$8,95 \mathrm{~mm}$ termasuk zona hambat sedang dan etanol $96 \%$ konsentrasi efektif pada 750 ppm termasuk zona hambat kuat. Namun untuk mendapatkan kandidat antibakteri yang baik diperlukan konsentrasi sekecil mungkin dengan hasil ataupun zona hambat yang besar sehingga dipilih etil asetat sebagai pelarut paling efektif karena dengan konsentrasi 250 ppm(Gambar 2) telah menghasilkan zona hambat $10,69 \mathrm{~mm}$ yang termasuk dalam zona hambat kuat.

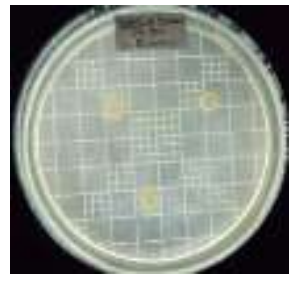

Gambar 2. Zona Hambat Ekstrak Etil Asetat 250 ppm Terhadap S. dysenteriae

\section{KESIMPULAN}

Berdasarkan hasil dari penelitin disimpulkan:

1. Perbedaan pelarut pada ekstraksi Padina sp. memberikan aktivitas antibakteri yang berbeda dimana aktivitas antibakteri dengan zona hambat terbaik terhadap bakteri Staphylococcus aureus yaitu dengan pelarut etil asetat dan aktivitas antibakteri dengan zona hambat terbaik terhadap bakteri Shigella dysenteriae yaitu dengan pelarut etanol $96 \%$.

2. Ekstrak alga coklat (Padina sp.) yang paling efektif untuk bakteri Staphylococcus aureus adalah pelarut etil asetat dengan konsentrasi 100 ppm yaitu 12,66 $\mathrm{mm}$ dan bakteri Shigella dysenteriae adalah pelarut etil asetat dengan konsentrasi 250 ppm yaitu 10,69 $\mathrm{mm}$.

\section{DAFTAR PUSTAKA}

Davis, W., dan Stout, T.1971. Disc PITE Methods of Microbiological Antibiotic Assay. Microbiology. Vol 22(4):659-665.

Demirel, Z., Yilmaz-Koz, F. F., KarabayYavasoglu, U.N., Ozdemir, G.,
Sukatar ,A. 2009. Antimicrobial and antioxidant activity of brown algae from the Aegean Sea. J Serb Chem Soc. Vol 7(4): 619-28.

Dulger, G. dan Dulger, B. 2014. Aktivitas Antibakteri dari dua alga coklat (Cystoseira compressa dan Padina pavonica) Melawan MethicilinResistant Staphylococcus aureus. Journal British Microbiology Research. 4(8): 918-923.

El-Fatimy, E. S. dan Said, A. A.2011. Aktivitas antibakteri ekstrak metanol pada alga laut (Padina Pavonia) dari Tolmeta Pesisir, Libya. Journal of American Science. 7(4): 745-751.

Harborne, J. B.1987. Metode Fitokimia: Penuntun Cara Modern Menganalisis Tumbuhan. ITB.Bandung.

Ismail, A., Leilaktari, Mehboobahmed, Henkbolhuis. 2016. Aktivitas Antimikrobakteri diasosiasikan dengan alga coklat (Padina pavonica). Journal Frontiers In Microbiology. Vol 7(1027): 1-13.

Kandhasamy, M., Arunachalam, K.D. 2008. Evaluation of in vitro antibacterial property of seaweeds of southeast coast of India. African Journal of Biotechnology. Vol 7(12) : 1958-1961. 
Kayalvizhi K., Subramanian V, Anantharaman P., Kathiresan K. 2012. Antimicrobial activity of seaweeds from the Gulf of Mannar. International Journal of Pharmaceutical Applications. Vol 3(2):06-314.

Kemer, K., Paransa D. S. J.,. Rumengan A. P. Dan Mantiri D. M. H. 2015.

Antibakteri Dari Beberapa Ekstrak Pada Alga Coklat. Jurnal Lppm Bidang Sains Dan Teknologi. Vol 2 (1): 73-81

Maharany, F., Nurjanah, Suwandi, R., Anwar E., Hidayat T. 2017. Kandungan Senyawa Bioaktif Rumput Laut Padina Australis dan Eucheuma Cottonii Sebagai Bahan Baku Krim Tabir Surya. Jurnal Jphpi.Vol 20 (1):11-18.

Markham, K.R. $1988 . \quad$ Cara Mengidentifikasi Flavonoid. TerjemahanKosasih Padamawinata. Penerbit ITB. Bandung.

Poduungge. 2012. Kandungan Fenol senyawa Fitokimia dan Aktivitas Antioksidan Rumput Laut Padina australis. Skripsi. Fakultas Perikanan dan Ilmu Kelautan Institut Pertanian Bogor.

Ponnanikajamideen, M., Malini, M., Malarkodi, C., Rajeshkumar S. 2014. Bioactivity and Phytochemical Constituents of Marine Brown Seaweed (Padina Tetrastromatica) Extract From Various Organic Solvents. International Journal of Pharmacy \& Therapeutics. Vol 5(2):108-112.

Priyanto. 2008. Farmakologi Dasar untuk Mahasiswa Keperawatan dan Farmasi.Leskonfi (Lembaga Studi dan Konsultasi Farmakologi). Jakarta.

Robinson, T. 1991. The Organic Constiuen of Higher Plants. Terjemahan Kosasih Padamawinata. Penerbit ITB. Bandung.
Robinson, T. 1995. Kandungan Organik tumbuhan Tingkat Tinggi. Penerbit ITB. Bandung.

Saloso, Y., Prajitno, A., Abadi, A, Z, Aulanni'am. 2011. Kajian Potensi Padina australis Sebagai Antibakteri Alami Dalam Pengendalian Bakteri Vibrio alginolitycus Pada Budidaya Ikan Kerapu Tikus (Cromileptes altivelis). Jurnal Bahan Alam Indonesia. Vol 7 (7): 365-369.

Taherpour A. dkk. 2016. Screening of marine algae (Padina sp.) from the Lengeh Port, Persian Gulf for antibacterial and antifungal activities. Journal of Coastal Life Medicine.Vol 4(9): 698-702.

Tuney U., Hilal B., Adirci, Nal D., Sukatar A. 2006. Antimicrobial Activities of the Extracts of Marine Algae from the Coast of Urla (Üzmir, Turkey). Jurnal of Science. Vol30 :171-175.

Wardani, E., Wahyudi P., Tantari, D., 2011. Uji Aktivitas Ekstrak Etanol 70\% dan n-Heksan Jamur Shitake (Lentinula edodes (Berk.)Pegler) Terhadap E. coli dan S. aureus. Jurnal Farma Sains. 1 (3):1-6.

Zailanie K. 2016. Penelitian Tentang Padina austrlis Menggunakan UVVIS, HPLC, dan Antibakteria. Journal of Life Science and Biomedicine. 6(1): 01-05.

Zatnika, A. 2007. Proses Ekstraksi dan Manfaat Alginat di Bidang Farmasi. Jurnal Sains dan Teknologi Indonesia. Vol 5:143-150. 